\title{
Overview of trends in crude palm oil production and economic impact in Malaysia
}

\author{
Ezerie Henry Ezechi ${ }^{1}$, Khalida Muda ${ }^{1}$ \\ ${ }^{1}$ School of Civil Engineering, Universiti Teknologi Malaysia, 81310, Johor Bahru, Malaysia \\ Corresponding author: khalida@utm.my
}

\begin{tabular}{llll} 
Article history & & \\
\hline Received & Received in revised form & Accepted & Available online \\
17 January 2019 & 16 March 2019 & 30 March 2019 & 30 March 2019 \\
\hline
\end{tabular}

\begin{abstract}
Palm oil has become a major edible and economic commodity with applications in various domestic and industrial processes. Malaysia is the second largest producer and exporter of crude palm oil (CPO). The oil palm industry in Malaysia significantly expanded and has become a major economic sector. The global demand of this precious commodity as food and fuel has caused a significant upsurge in production of oil palm. A tremendous increase of CPO production has been witnessed in the Malaysian oil palm industry over a decade now. The CPO production in 2011 was about 11.8 million tonnes but skyrocketed to 19.92 million tonnes in 2017. Beyond the revenue generation from the oil palm industry in Malaysia, there is significant investment in research and development that has resulted in the discovery of more sustainable ways to manage oil palm waste. This overview therefore seeks to evaluate the trend in crude palm oil production in Malaysia and its economic contribution to the nation from 2007-2017. Various indices associated with crude palm oil production such as planted land area, volume of exported CPO, revenue generated from the exported CPO, average annual price of exported CPO, fresh fruit yield and oil extraction rate was discussed. This overview is limited to crude palm oil production within 2007-2017 and seeks to discuss the trend within the context of the timeframe.
\end{abstract}

Keywords: Crude palm oil, Malaysia, Production, Land area, Revenue

\section{Introduction}

The oil palm tree (Elaeis guineensis) is an important economic tropical plant native to Africa. The oil palm has significant socioeconomic and cultural impact on the inhabitants of the communities where it is grown. However, the oil palm tree and its industry are also associated with the generation of huge amount of biomass waste.

There are two known species of the oil palm tree which are Elaeis guineensis and Elaeis oleifera. The former is the widely cultivated specie whereas the latter is less cultivated [1]. Elaeis guinnensis is monecious specie that belongs to the Aracaceae palm family and Arecoideae sub-family. Elaeis guineensis represents the tenera variety which is the commercially planted specie $[1,2]$. The oil palm tree has a single-sex inflorescence that accommodates both male (staminate) and female (pistillate) flowers in alternating cycle and reduces the chances of self-pollination on the same plant [1, 3]. These oil palm trees can favorably grow under conditions of sunshine, hot climate, wet and humid tropic conditions with a relatively high rainfall rate [4].

The oil palm industry has emerged as a stable pillar of the Malaysia's economic plan and growth. Malaysia dominated the oil palm world for decades as the harbinger for $\mathrm{CPO}$ production and export $[4,5]$.
However, the situation changed in 2007 when Indonesia, a neighboring Southeast Asian country with similar climatic conditions overtook Malaysia as the juggernaut in oil palm production and have retained the position till date [6].

The first commercial scale oil palm plantation in Malaysia was established in Tenamaran Estate, Selangor in 1917. The second commercial oil palm plantation was established in Elmina Estate in 1920. In May 2017, Malaysia celebrated the centennial milestone in the oil palm industry which reflected on the growth of the industry so far. Oil palm industry is a major source of revenue and emerged the second and fourth largest contributors to the national gross outputs in 2009 and 2014, contributing over 25.04 billion USD and 22.31 billion USD, respectively [6].

The success of the Malaysian oil palm industry could be attributed to favorable government contributions and the integration of various stakeholders and agencies such as the Malaysian Palm oil Board (MPOB), Malaysian Palm Oil Council (MPOC), Forest Research Institute Malaysia (FRIM), Palm Oil Research Institute of Malaysia (PORIMP), land settlement schemes such as Federal Land Development Agency (FELDA), Federal Land Consolidation and Rehabilitation Authority (FELCRA) and Rubber Industry Smallholders Development Authority (RISDA), private sector participation and contributions from academicians in some local universities. Additionally, 
the strategic economic plans of the government which continues to set feasible target for the oil palm industry also immensely contributed to the development of the sector. Research and development has been an integral part of the growth of the Malaysia oil palm industry with greater focus on innovation and technologies.

With a total land mass of about 32.98 million hectares [7], oil palm plantations alone occupies about $17.62 \%$ as at 2017 in Malaysia. This is in stark contrast to the 54,000 hectares occupied by the oil palm industry in 1960 .

Nonetheless, there are some down sides to the oil palm growth in Malaysia especially with reference to the environment. It was reported that deforestation caused about 5 million hectares of forest cover loss representing about $20 \%$ of forest land in Malaysia [8]. The continued expansion of the oil palm industry, deforestation that denude forest covers and conversion of natural rainforest, peat swamp forest, cropland or other land types into oil palm plantations has wider environmental and social implications including loss of biodiversity, Green House Gas (GHG) emission from carbon stored in biomass, soil (peatland) forest fires, respiratory diseases, land tenure and human rights conflicts [8-10].

Oil palm is a lucrative crop in terms of yield and productivity. It is estimated that oil palm yield can reach about 4-5 metric tons of oil per planted hectare. This is in stark contrast with other oilseeds such as rapeseed which yields about 1 metric ton per hectare, soybean ( 0.375 metric ton per hectare) and sesame ( 0.16 metric per hectare), respectively $[11,12]$. The increase in price and profitability from oil palm production is an added incentive for oil palm producers to expand their business. Additionally, the widespread demand of oil palm for various purposes also increases the desire for expansion.

In light of the profitability and environmental consequences of oil palm processing, there is a dire need to review the progress of this industry so far in terms of $\mathrm{CPO}$ production and the factors that significantly contributed to present status of $\mathrm{CPO}$ production in Malaysia.

The principal objective of this overview is to compile national level data on CPO production for the past 10 years in Malaysia and highlight the progress and or decline made thus far. An overview of CPO production in Malaysia between 2007 and 2017 was conducted by collecting data from publicly available national and international statistical databases, government reports and academic databases.

\section{Methodology}

\subsection{Data collection}

The data was systematically collected through extensive search in various databases such as national ministries, policy literatures, national agencies and major international research institutes. These data were analyzed and compared with each other to identify the most consistent database, appropriate for this study.

\subsection{Data Analysis}

A desktop data analysis was conducted using Microcal Origin Software 6.0. Origin is a multi-facet data analysis software used for graphing of simple and complex data. It has a wide range of data processing tools and can generate a series of datasets by formula. It has an easy to use interface designed to help all levels of users. It has advanced features that can enable customization of data and automatic data or parameter update. It can also connect with other applications such as MATLAB ${ }^{\mathrm{TM}}$, LabVIEW $^{\mathrm{TM}}$ or Microsoft Excel.

\subsection{Variables analyzed}

Data for crude palm oil (CPO) production, planted land area, annual land increment, CPO export, CPO export revenue, annual $\mathrm{CPO}$ price, fresh fruit bunch (FFB) yield and oil extraction rate (OER) were obtained and analyzed using Origin 6.0 software. Several bar charts and pie charts were generated.

\subsection{Annual increment on land area}

The annual increment on land area was calculated as the sum of the difference between a present year and the previous year. The difference was described in the following expression

$$
\mathrm{A}-\mathrm{B}=\mathrm{C}
$$

Where $\mathrm{A}$ is the land area in a present year (hectare), $\mathrm{B}$ is the land area in the previous year (hectare), $\mathrm{C}$ is the difference between A and B (hectare).

\section{Results and discussion}

\subsection{Data collection}

The data from various database evaluated showed some discrepancies. The database evaluated include Malaysian Palm Oil Board [13], Food and Agriculture Organization of the United Nations [14], Indonesian Bureau of Statistics [15] and Department of Statistics, Malaysia [16]. The most consistent database with a far more reliable data was the Malaysian Palm Oil Board [13] and Food and Agriculture Organization of the United Nations[14]. Palm oil statistics from the Department of Statistics Malaysia was closely in agreement with the data from MPOB on some variables while it differed in other variables. For instance, similar value of 20.18 was obtained for the Fresh Fruit Bunch 
yield from Department of Statistics, Malaysia and MPOB whereas the land area recorded by MPOB and the Department of Statistics, Malaysia in 2008 was 4.49 Mha and 3.95 Mha, respectively. The statistics from the Food and Agriculture Organization of the United Nations were in close agreement with that of MPOB. The data from Indonesian Bureau of Statistics was not used due to wide disparity. Data from MPOB and FAOSTAT were correlated and used in this study. Academic literatures such as $[8,17-20]$ gave a good insight into the data used.

\subsection{Oil Palm Planted Land Area}

In compliance with the 1990s agreement with the United Nations, Malaysian oil palm expansion has rapidly slowed down. Statistics from 2007 to 2017 have shown that the industry prefer innovation and technological intensification to land expansion. In examining the causes of forest cover change in Peninsular Malaysia, Miyamoto et al. [21] found that deforestation for oil palm expansion has significantly reduced in Peninsular Malaysia in the mid-1980s and oil palm expansion is no longer a cause of deforestation. This is in agreement with the recent data for oil palm planted area in subsequent years. For instance, the data from 2007 to 2017 shows that land area for oil palm plantations increased from 4.3 to 5.81 million hectares, an addition of only about 1.51 million hectares within that timeframe as shown in Figure 1. The land area expansion from 2007 to 2017 in Figure 1 indicates a slow increment from 4.3, 4.49, 4.691, 4.85, 5.00, 5.08, $5.23,5.39,5.64,5.74$ and to 5.81 million hectares, respectively. The expansion of the Malaysia oil palm industry occurs at a very slow pace largely due to two reasons viz the government's pledge to retain at least $50 \%$ forest cover in the late 1990s and the corporate strategy of Malaysian palm oil stakeholders to invest in palm oil plantations abroad [22].

In the 1980s, Malaysia faced severe rebuke and criticisms from environmentalists due to logging practices in Malaysia's lush rainforest. Some European governments placed embargo on Malaysian timber due to deforestation related reasons. In a way of peace and demonstration of sustainable practice, Malaysia pledged to maintain $50 \%$ of its forested land area at the United Nations Conference on Environment and Development in 1992 [22]. At the United Nations Conference on Sustainable Development in Rio De Janeiro, Brazil in 2012, the Malaysia government, through the Honourable Minister of Natural Resources and Environment, Dato' Sri Douglas Uggah Embas restated their commitment to the $50 \%$ forest cover pledge, pointing out that Malaysia has about 56.4\% of forest cover [23]. However, at the United Nations Framework Convention on Climate

Vol. 4 No. 1, 19-26
Change (UNFCCC) Conference of the Parties (COP) 22 in Marrakech in 2016, the Malaysia's Minister for Environment and Natural Resources, Dr. Wan Junaidi Tuanku Jaafar reiterated Malaysia's commitment to the pledge and stated that Malaysia currently has about $54.5 \%$ forest cover [24], a decrease of about of $1.9 \%$ from 2012.

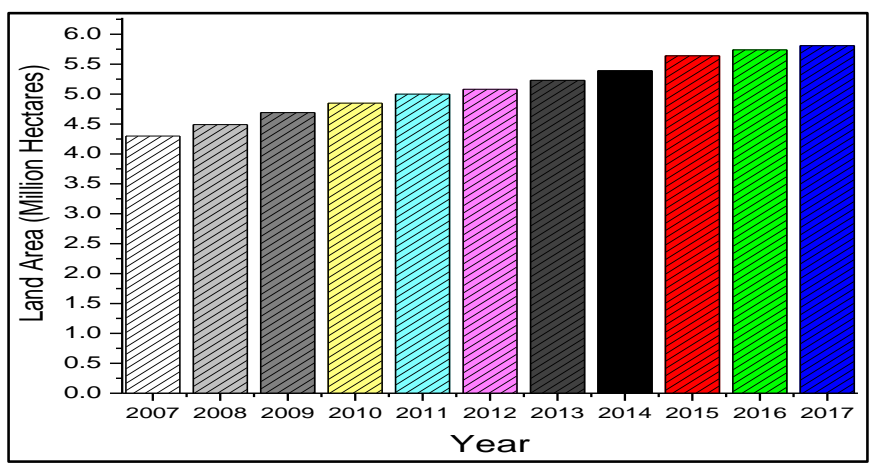

Figure 1: Land Area for Oil Palm Plantations in Malaysia [13]

The Malaysia government's voluntary pledge to retain about $50 \%$ of its forest cover has been a positive check on the obliteration of forest cover. While this pledge is voluntary and reversible, it has curtailed the invasion of forest cover for the time-being. In view of this pledge, the Malaysian government has enacted several polices that enabled the oil palm industry to flourish despite the $50 \%$ cover forest pledge. Several agencies related to the oil palm industry plays vital role in the development of the industry. MPOB has particularly contributed to the growth of the industry through research and development and technical advisory services to the industry [25].

The average annual land area increment, calculated as the average sum of the difference from 2007-2017 in Figure 2 is as low as 150,623 hectares/annum. With all the tempting profit and revenue obtainable from further expansion, this trend is significantly encouraging and remarkable considering that Malaysia desires to comply with its agreement to reserve about $50 \%$ of its forest cover.

The key stakeholders and their involvement in the Malaysian oil palm industry have been classified into different categories. The data in 2017 shows that private estates/company dominate the Malaysian oil palm industry utilizing about 3,543,429 hectares of land, followed by independent small holders with about 979,758 hectares of land [13]. Other stakeholders include Federal land development authority (FELDA) with about 704,811 hectares, state schemes and government agencies with about 347,632 hectares, federal land consolidation and rehabilitation authority 
(FELCRA) with about 169,158 hectares and Rubber Industry Smallholders Development Authority with about 66,357 hectares as shown in Figure 4. This is in stark contrast with countries such as Thailand whose oil palm industry is dominated by smallholders [26].

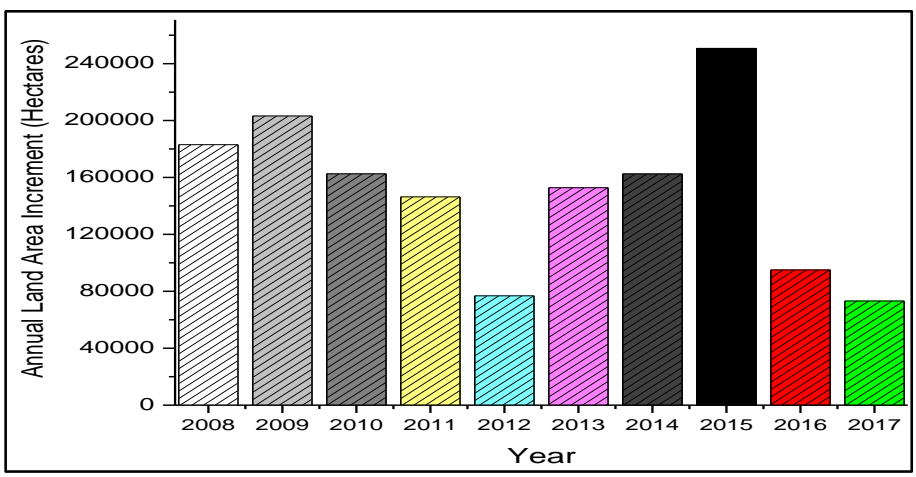

Figure 2: Annual Increment on Land Area in Malaysia (2008-2017)

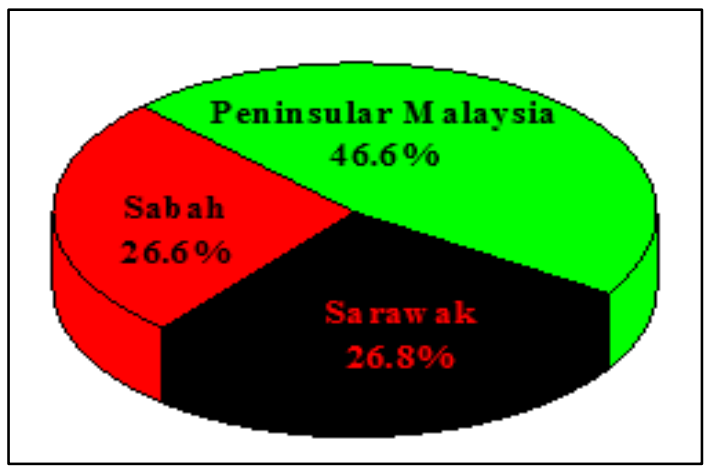

Figure 3: Planted Land Area by State in Malaysia [13]

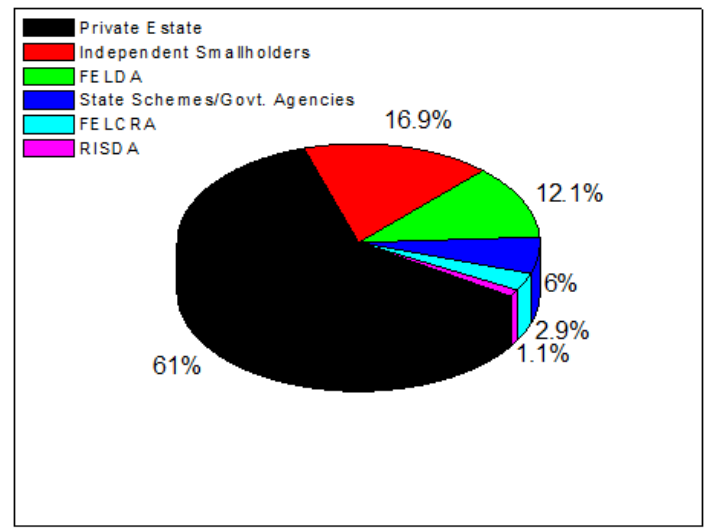

Figure 4: Land Owners by Category [13]

\subsection{Crude Palm Oil Production}

Malaysia is the second largest producer and exporter of crude palm oil. The crude palm oil production in Malaysia from 2007 to 2017 has been a mix of up and downtrend due to several environmental and agricultural reasons. Figure 5 shows that $\mathrm{CPO}$ production in Malaysia was about 15.82 million tonnes in 2007 but increased to 17.73 million in 2008. In 2009, CPO production decreased to 17.56 million tonnes, decreased to 16.99 million tonnes in 2010 , increased to 18.91 million tonnes in 2011 , marginally decreased to 18.79 million tonnes in 2012 , increased to 19.22 million tonnes in 2013, further increased to 19.67 million tonnes in 2014, marginally increased to 19.96 million tonnes in 2015 , significantly decreased to 17.32 million tonnes in 2016 and significantly increased to 19.92 million tonnes in 2017.

The decreased in CPO production in 2010, 2012 and 2016 were a result of unfavorable weather conditions caused by the El-Nino and La-Nina phenomena [27]. ElNino and La-Nina, two phenomenon that occurs due to the variation in the ocean temperatures of the equatorial pacific could lead to extreme changes in levels of rainfall and significantly affect $\mathrm{CPO}$ production. As a consequence, when rainfall reduces, the FFB development stage could be stressed and cause low FFB yield. However, at higher than average rainfall, CPO production also decreases [28]. Oil palm, as a tropical plant requires annual rainfall of about $1500-2000 \mathrm{~mm}$ or more, without a defined dry season. Oil palm also requires maximum and minimum temperatures in the range of $29-33^{\circ} \mathrm{C}$ and $22-24{ }^{\circ} \mathrm{C}$, respectively for optimal growth and production. A constant sunlight of about 5 hours/day is necessary for quality yield [28, 29]. CPO production occasionally decreases when these climatic conditions are not favorable for the oil palm tree.

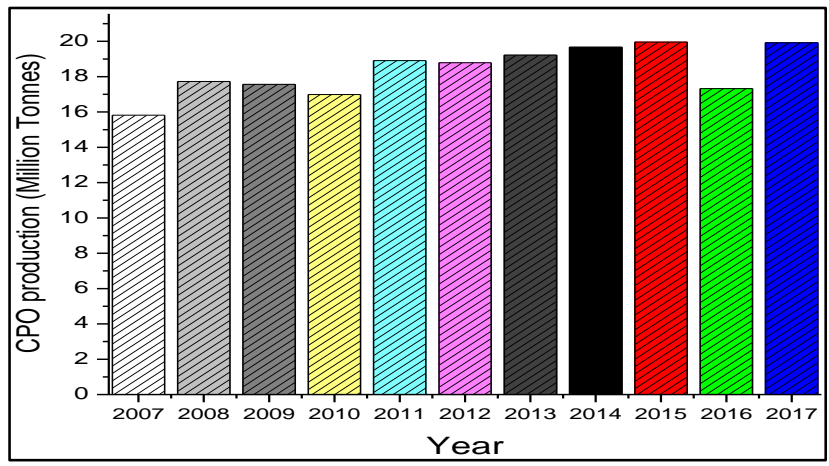

Figure 5 Annual CPO productions in Malaysia [13]

Re-planting of palm trees also influenced CPO production. For instance, between 2009-2010, about 207,754 hectares of old oil palm trees were hewed and replanted [27]. This also contributed to the decrease of CPO production in 2010. In 2011, 2013, 2014, 2015 and 2017, CPO production were positively influenced by better weather conditions and increased yield arising from the maturity of the re-planted oil palm trees

http://dx.doi.org/10.22135/sje.2019.4.1.19-26 
The rapid expansion of the planted area in Sarawak from $1,021,587$ hectares in 2011 to $1,555,828$ hectares in 2017 caused an annual increase in crude palm oil production in Sarawak from 2.2 million tonnes in 2010 to 4.13 million tonnes in 2017. In contrast to the neighboring State of Sabah, CPO production in 2010 and 2017 were 5.3 million tonnes and 5.22 million tonnes, respectively $[13,27]$. The CPO production in Peninsular Malaysia in 2017 was about 10.58 million tonnes as shown in Figure 6.

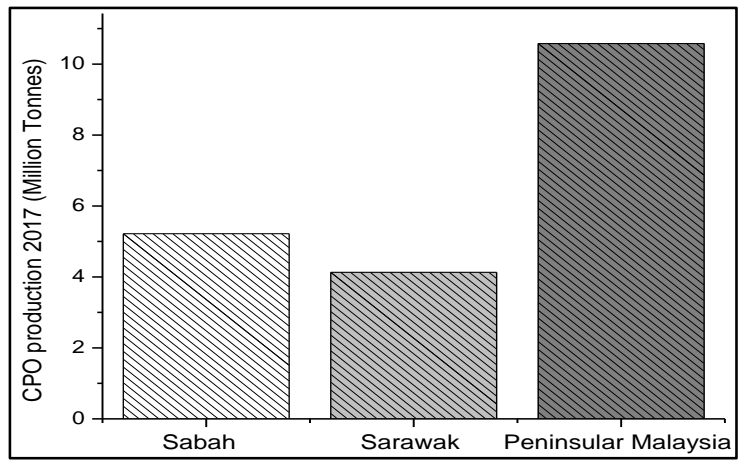

Figure 6: CPO production in 2017 [13]

\subsection{CPO Export and Revenue}

The oil palm industry is the fourth economic sector in Malaysia [30]. Oil palm industry is an economic venture in Southeast Asia and contributes significantly to national and province GDP [31]. Palm oil generates huge amount of revenue for Malaysia as well as huge numbers of jobs. Few literatures have listed varying job figures for the oil palm industry in Malaysia. According to the Department of Statistics Malaysia, the total number of person employed during the last pay period in 2014 was 451,507 persons [15]. However, Sovacool and Drupady [32], reported that the oil palm industry employs more than 800,000 persons. The disparity in this figures simply imply that the oil palm industry in Malaysia is a creator of significant direct and indirect jobs.

Malaysia is the second largest exporter of crude palm oil. However, the CPO exportation from 2007 to 2017 shows some fluctuations due to annual CPO production. For instance CPO exportation in 2009 and 2010 was about 15.88 million tonnes and 16.66 million tonnes whereas CPO production in 2009 and 2010 was about 17.56 and 16.99 million tonnes, respectively [27]. Figure 7 shows the crude palm oil exportation from 2007 to 2017 . The export of crude palm oil reached 13.75 million tonnes in 2007 , increased to 15.41 million tonnes in 2008, marginally increased to 15.88 million tonnes in 2009, increased to 16.66 million tonnes in 2010, increased to 18 million tonnes in 2011 , decreased to 17.56 million tonnes in 2012 , increased to 18.15 million tonnes in 2013, decreased to 17.31 million tonnes in
2014, increased to 17.45 million tonnes in 2015, decreased to 16.05 million tonnes in 2016 and increased to 16.56 million tonnes in 2017 , respectively [13].

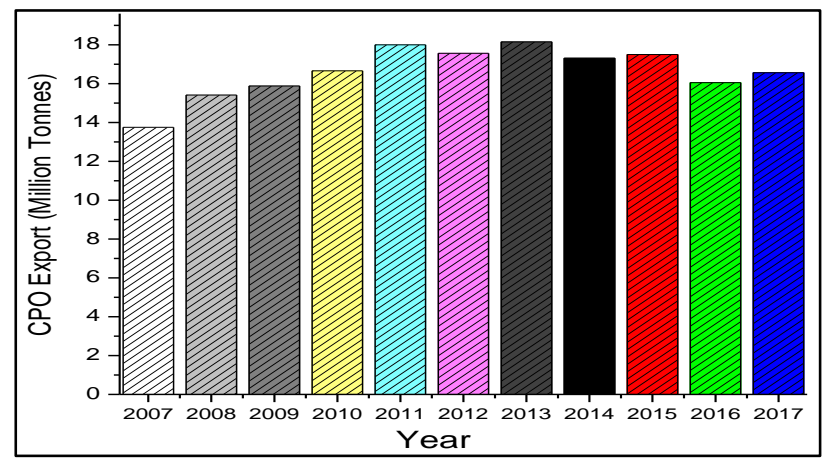

Figure 7: Export of crude palm oil [13]

The revenue generated from $\mathrm{CPO}$ exportation from 2007 to 2017 is shown in Figure 8. There were significant fluctuations in revenue generation owing largely to CPO prices. This was attributed to increase in domestic and international demand of oil palm [12]. In some years, high revenue generation was recorded even at lower CPO exportation due to the increases in price of CPO. For instance, in 2012, about 17.56 million tonnes of CPO was exported whereas higher volume of 18.15 million tonnes was exported in 2013. However, the revenue generated in terms of CPO exported in 2012 was higher (RM 52.96 million) compared to 2013 when RM 45.27 million was generated. This was a clear effect of the disparity in annual export price of CPO. In 2012, the annual average export price of CPO was about RM 2,764 per tonne whereas it was about RM2,371 per tonne in 2013, indicating a clear CPO price difference of RM 393 between 2012 and 2013. A similar trend was also noticed in 2014 and 2015. A lower CPO export volume of 17.31 million tonnes generated revenue of about RM 44.50 million in 2014 whereas a higher CPO export volume of 17.50 million tonnes generated revenue of about RM 41.26 million in 2015 due to the differences in the annual CPO prices. The average annual CPO price in 2014 was higher (RM 2,383.50) compared to the price (RM 2,153.50) in 2015. Crude palm oil prices has several determinants such as demand, tightening policies on oil seeds, regional political unrest, impact of weather conditions on fresh fruit yield and oil seeds, global financial crisis and palm oil stock volume [13]. 


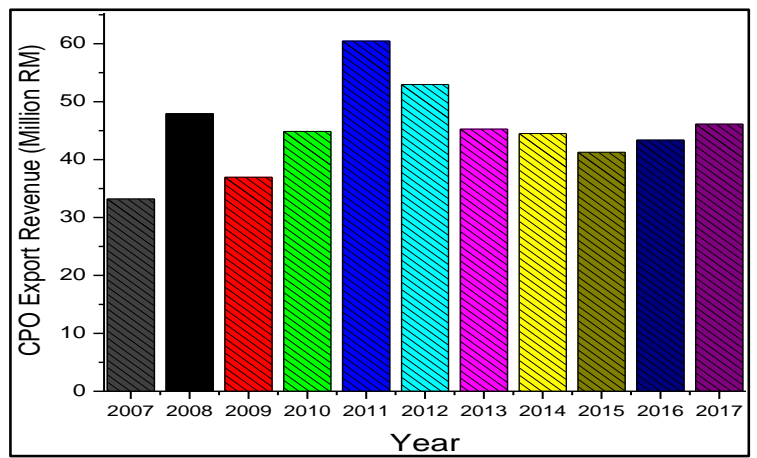

Figure 8: CPO Export revenue generated [13]

The average annual CPO price from 2007 to 2017 is shown in Figure 9. The plot shows that average annual palm oil prices were higher and exceeded RM 2,500 per tonne in 2010, 2011, 2012, 2016 and 2017, respectively. The highest export CPO price was recorded in 2011 with a record average annual price of RM 3,219. These favorable higher prices contributed to higher annual export revenue even at lower CPO production.

The major export route for Malaysia CPO has been China, European Union, India, Pakistan, USA, Vietnam, Japan and other countries. China has been the major consumer of Malaysia CPO from 2002 to 2014. However, that trend changed when India became the highest importer of Malaysia CPO in 2015 due to higher importation of seed oils in China.

\subsection{Fresh Fruit Yield and Oil Extraction Rate}

The fresh fruit yield is a measure of the productivity of oil palm plantation. It can give an estimate of the potential CPO production of an entire plantation. In the oil palm industry, production efficiency is evaluated by yield and oil extraction rate. Malaysian oil palm industry has operated at a fairly stable yield and oil extraction rate [22].

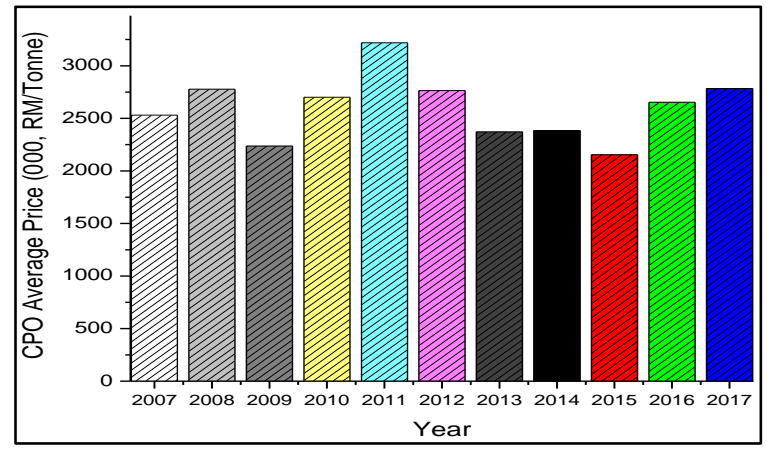

Figure 9: Average annual CPO price from 2007-2017

After cultivation, oil palm tree begins to yield fruits between 3-4 years depending on the specie and planting conditions. Additional 6 months is required to enable the fruits mature prior to harvest. The oil palm fruits appear in bunches made up of oily pericarp, shell and kernel
[33]. The yield represents the output of the oil palm plantations in terms of fresh fruit bunch per hectare whereas the oil extraction rate represents the volume of oil produced from the FFBs.

Several factors such as seed quality, plantation management, age, weather conditions and punctual harvesting can influence oil palm yield [13]. The fresh fruit yield from 2007-2017 as shown in Figure 10 showed a fluctuating trend.

The fresh fruit yield in 2007 reached 19.03 tonnes/hectare, increased to 20.18 tonnes/hectare in 2008 , decreased to 19.20 tonnes/hectare in 2009 , further decreased to 18.03 tonnes/hectare in 2010 , increased to 19.69 tonnes/hectare in 2011, decreased to 18.89 tonnes/hectare in 2012, increased to 19.02 tonnes/hectare in 2013 , decreased to 18.63 tonnes/hectare and 18.48 tonnes/hectare in 2014 and 2015, drastically decreased to 15.91 tonnes/hectare in 2016 and significantly increased to 17.89 tonnes/hectare in 2017 , respectively.

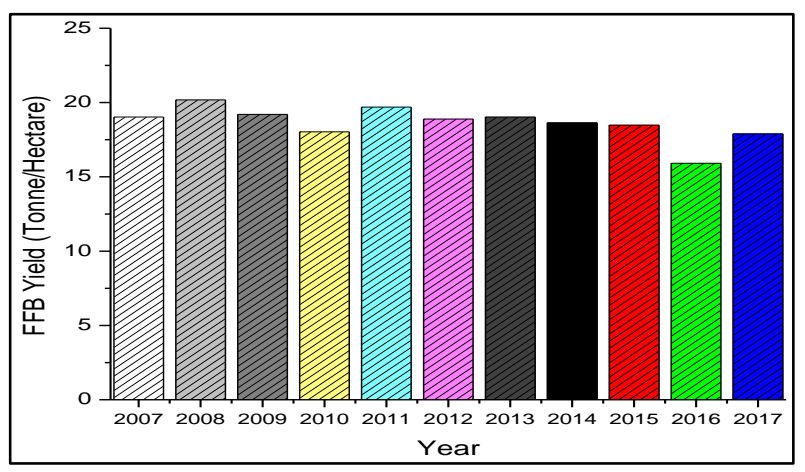

Figure 10: Fresh fruit yield from 2007-2017 [13]

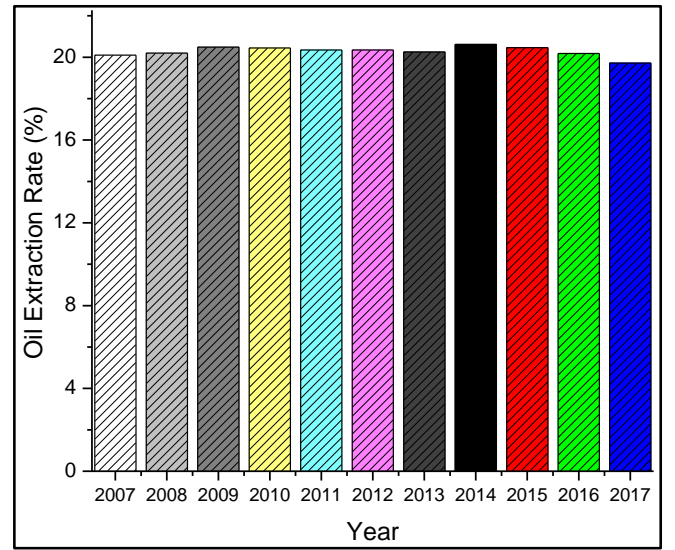

Figure 11: Oil extraction rate from 2007-2017 [13]

Climatic conditions arising from the El-Nino phenomena, prolonged dry weather and inadequate rainfall caused the drastic reduction of oil palm yield in 2016. Others factors that influenced the oil palm yield from 2007-2017 include re-planting of trees [13]. 
The oil extraction rate (OER) showed a near stable output from 2007 to 2017 as shown in Figure 11. The OER in 2007 reached 20.1, insignificantly increased to 20.2 in 2008 , increased to 20.49 in 2009 , decreased to $20.45,20.35,20,35,20.25$ in $2010,2011,2012,2013$, increased to 20.62 in 2014 , decreased to $20.46,20.18$ and 19.72 in 2015, 2016 and 2017, respectively. The decrease of OER in 2013 was caused by unfavorable weather conditions arising from rainfalls, hot and dry weather and low quality crops from matured areas. However, the improvement in 2014 was as a result of good weather conditions and good quality crops [13].

\section{Conclusion}

The Malaysian oil palm industry has made a significant progress both in crude palm oil production and technology development. There has been a successful strategic stringent expansion of oil palm planted area in order to comply with the agreement to preserve $50 \%$ of its forest cover. This strategy is the birth of intensive technological investment with the objective of achieving optimum crude oil production from the available planted area. However, while there was a significant bump in fresh fruit yield with the investment in research and development, the fresh fruit yield has been stagnant for almost a decade now within the range of 19-20.5 tonnes/hectare except in 2016 and 2017 where it was below 17 tonnes/hectare. While the Malaysian oil palm industry prefer technological intensification over land expansion, it is therefore necessary for the industry to embark on further intellectual collaborations with the aim of improving the fresh fruit bunch yield. The continual expansion of oil palm plantation on peatsoil may be consequential over a long period. Appropriate investment can be channeled to neighboring countries with similar climatic conditions whose croplands are underused. Although oil palm biomass waste is not within the scope of this overview, it is worth mentioning due to its deleterious impact on the environment. More technological investment is required to curtail the environmental quandary associated with oil palm waste and to engage in the intensive recovery of value added products from oil palm biomass waste.

\section{References}

[1] L. Baudouin, C. Baril, A. Clément-Demange, T. Leroy, and D. Paulin, "Recurrent selection of tropical tree crops," Euphytica, vol. 96, pp. 101114, 1997.

[2] H. H. Zulkifli, M; Chan, K W; Choo, Y M and Mohd Basri, W, "Life cycle assessment for oil palm fresh fruit bunch production from continued land use for oil palm planted on mineral soil (Part
2)," Journal of Oil Palm Research, vol. 22, pp. 887-894, 2010.

[3] H. Adam, M. Collin, F. Richaud, T. Beulé, D. Cros, A. Omoré, L. Nodichao, B. Nouy, and J. W. Tregear, "Environmental regulation of sex determination in oil palm: current knowledge and insights from other species," Annals of Botany, vol. 108, pp. 1529-1537, 2011.

[4] S. Yusoff, "Renewable energy from palm oilinnovation on effective utilization of waste," Journal of Cleaner Production, vol. 14, pp. 87-93, 2006

[5] J. Sayer, J. Ghazoul, P. Nelson, and A. K. Boedhihartono, "Oil palm expansion transforms tropical landscapes and livelihoods," Global Food Security, vol. 1, pp. 114-119, 2012.

[6] M. F. Awalludin, O. Sulaiman, R. Hashim, and W. N. A. W. Nadhari, "An overview of the oil palm industry in Malaysia and its waste utilization through thermochemical conversion, specifically via liquefaction," Renewable and Sustainable Energy Reviews, vol. 50, pp. 1469-1484, 2015.

[7] S. M. Shafie, T. Mahlia, H. Masjuki, and A. Andriyana, "Current energy usage and sustainable energy in Malaysia: a review," Renewable and Sustainable Energy Reviews, vol. 15, pp. 43704377, 2011.

[8] B. Wicke, R. Sikkema, V. Dornburg, and A. Faaij, "Exploring land use changes and the role of palm oil production in Indonesia and Malaysia," Land Use Policy, vol. 28, pp. 193-206, 2011.

[9] H. K. Gibbs, M. Johnston, J. A. Foley, T. Holloway, C. Monfreda, N. Ramankutty, and D. Zaks, "Carbon payback times for crop-based biofuel expansion in the tropics: the effects of changing yield and technology," Environmental Research Letters, vol. 3, p. 034001, 2008.

[10] L. P. Koh and D. S. Wilcove, "Is oil palm agriculture really destroying tropical biodiversity?," Conservation Letters, vol. 1, pp. 60-64, 2008.

[11] S. Lim and L. K. Teong, "Recent trends, opportunities and challenges of biodiesel in Malaysia: an overview," Renewable and Sustainable Energy Reviews, vol. 14, pp. 938-954, 2010.

[12] I. Mukherjee and B. K. Sovacool, "Palm oil-based biofuels and sustainability in southeast Asia: A review of Indonesia, Malaysia, and Thailand," Renewable and Sustainable Energy Reviews, vol. 37, pp. 1-12, 2014.

[13] A. D. Kushairi. (2017), Director General of MPOB. Economic and Industry Development Division. Overview of the Malaysian Oil Palm 
Industry Available: http://bepi.mpob.gov.my/ index.php/en/

[14] FAOSTAT, "Crop and livestock products; Area planted of oil Palm 2007-2014. Food and Agriculture Organization of the United Nations " 2014. http://www.fao.org/faostat/en/\#data/TP

[15] BPS. (2015, Indonesia Oil Palm Statistics. Statistics Indonesia Available: https://www.bps.go.id/

[16] EPU. Statistics of major Agriculture products. Economic Planning Unit, Ministry of Economic Affairs, Malaysia. Available: http://www.epu.gov.my/en/economicstatistics/statistic-major-agriculture

[17] B. Jalani, Y. Basiron, A. Darus, K. Chan, and N. Rajanaidu, "Prospects of elevating national oil palm productivity: a Malaysian perspective," Oil Palm Industry Economic Journal, vol. 2, pp. 1-9, 2002.

[18] A. Kushairi, S. K. Loh, I. Azman, E. Hishamuddin, M. Ong-Abdullah, Z. B. M. N. Izuddin, G. Razmah, S. Sundram, and G. K. A. Parveez, "Oil palm economic performance in Malaysia and R\&D progress in 2017," Journal of Oil Palm Research, vol. 30, pp. 163-195, 2018.

[19] R. Khatun, M. I. H. Reza, M. Moniruzzaman, and Z. Yaakob, "Sustainable oil palm industry: The possibilities," Renewable and Sustainable Energy Reviews, vol. 76, pp. 608-619, 2017.

[20] W. P. Q. Ng, H. L. Lam, F. Y. Ng, M. Kamal, and J. H. E. Lim, "Waste-to-wealth: green potential from palm biomass in Malaysia," Journal of Cleaner Production, vol. 34, pp. 57-65, 2012.

[21] M. Miyamoto, M. M. Parid, Z. N. Aini, and T. Michinaka, "Proximate and underlying causes of forest cover change in Peninsular Malaysia," Forest Policy and Economics, vol. 44, pp. 18-25, 2014.

[22] H. Varkkey, A. Tyson, and S. A. B. Choiruzzad, "Palm oil intensification and expansion in Indonesia and Malaysia: Environmental and sociopolitical factors influencing policy," Forest Policy and Economics, vol. 92, pp. 148-159, 2018.

[23] D. Embas, "Statement by the honourable dato'sri douglas unggah embas, minister of natural resources and environment, Malaysia," in United Nations Conference on Sustainable Development, 2012.
[24] Jaafar W.J.T. (2016), Statement by the Honourable Minister of Natural Resources and Environment, Malayia, Dato Sri Dr. Wan Junaidi Tuanku Jaafar for the Joint High Level Segment of COP22/CMP12/CMA1, 7-18 November, 2016, Marrakech, Morocco.

[25] M. B. Wahid, S. Abdullah, and I. Henson, "Oil palm-achievements and potential," in New directions for a diverse planet, Proceedings of the 4th International Crop Science Congress, 2004.

[26] M. Willems. (2015), Sustainable Palm oil production in Thailand, exploring environmentally and socially sustainable pathways for palm oil production in Thailand. [M.Sc Thesis in Environmental Policy Group, Wageningen University].

[27] C. Y. May. (2010), Director General of MPOB, Economic and Industry Development Division Overview of the Malaysian Oil Palm Industry. Available: http://bepi.mpob.gov.my/index.php/en/

[28] N. N. Kamil and S. F. Omar, "The Impact of El Niño and La Niña on Malaysian Palm Oil Industry," Oil Palm Bulletin, vol. 74, pp. 1-6, 2017.

[29] S. M. A. a. N. B. Nur Ain Mohd Hassan, "Relationship between severe El Nino Phenomena and Malaysia's Palm oil production - A VECM Approach," Oil Palm Industry Economic Journal vol. 18 pp. 1-8, 2018.

[30] A. F. Alam, A. Er, and H. Begum, "Malaysian oil palm industry: prospect and problem," Journal of Food, Agriculture \& Environment, vol. 13, pp. 143-148, 2015.

[31] K. Obidzinski, R. Andriani, H. Komarudin, and A. Andrianto, "Environmental and social impacts of oil palm plantations and their implications for biofuel production in Indonesia," Ecology and Society, vol. 17, 2012.

[32] B. K. Sovacool and I. M. Drupady, "Innovation in the Malaysian waste-to-energy sector: applications with global potential," The Electricity Journal, vol. 24, pp. 29-41, 2011.

[33] S. Sumathi, S. Chai, and A. Mohamed, "Utilization of oil palm as a source of renewable energy in Malaysia," Renewable and Sustainable Energy Reviews, vol. 12, pp. 2404-2421, 2008. 